\title{
AN INVESTIGATION INTO THE BENEFITS AND CONSTRAINTS OF SHIFTING FREIGHT TRAFFIC FROM ROADS ONTO HIGH-SPEED RAILWAYS
}

\author{
INARA WATSON, AMER ALI \& ALI BAYYATI \\ School of the Built Environment and Architecture, London South Bank University, UK
}

\begin{abstract}
The environmental, economic and social impacts associated with the continuing increase in the global freight transport has necessitated more than ever the need for a more effective and sustainable freight transport system. High Speed Railways (HSR) may provide the solution as they have the ability to move goods quickly, safely and economically which can sufficiently improve the trade links within vast regions such as the European Union and extend that to Asian countries. The major issues concerning freight transport are greenhouse gas emissions and dependency on fossil fuel which mean that railway freight transport particularly HSR freight would be the most competitive mode. Many countries have invested in developing HSR but at present, HSR is more regularly used for passengers than for freight although there are an increasing number of countries who operate HSR freight services. Some HSR systems are not profitable as the demand for travel is not sufficient and there is a significant larger haulage capacity available, and thus they need additional funding from governments. Shifting freight from roads onto railways will improve the economic performance of HSR, reduce the amount of fuel used by the transport industry and reduce the greenhouse gas emission. This research considers the future trends and possibilities of shifting freight from roads to HSR lines and analyses the operational and technological constrains concerning freight traffic and the corresponding capabilities of HSR. Most of the data and information used in the research are gathered from relevant online sources including in depth research of the HSR in selected countries, available railway statistics and European and Institutional publications. The expected outcome of this research may contribute to developing more suitable means to improve the economic, environmental and social sustainability of HSR particularly for freight transport.
\end{abstract}

Keywords: high-speed railways, freight transport, impact, sustainability.

\section{INTRODUCTION}

The growing amount of express delivery increases the opportunity for HSR to take part in the supply chain and this may come from the removal of barriers to international trade and globalization and increasing specialization and global communication. The economies of various countries around the world rely on delivering exports and bringing imports from other countries which heavily depend on speed, reliability and connectivity. All of these can be offered by HSR services. At present, the economic performance of the majority of HSR systems show that it is very difficult and in many cases impossible to recover their construction costs from passenger revenue alone, except in highly dense corridors such as Tokyo-Osaka or Paris-Lyon. Recovery of construction costs of HSR systems can be possible only through intensive use of their infrastructure. The HSR network can provide not only passenger transportation but express freight movement. Conventional railway networks may move large and heavy cargoes, but high-value and time-sensitive cargos are more suitable for transport by HSR in mid-range and long distances. It will increase the revenue of HSR and reduce the negative impact on the environment from road and air transportation, reduce congestion and open new commercial opportunities for communities. There is a need to look at possible ways to introduce express delivery of goods by HSR which will not affect the 
passenger transportation but increase the HSR revenue. The two players involved in express delivery of goods by HSR are the railway and express delivery companies.

\section{CURRENT SITUATION CONCERNING \\ FREIGHT TRANSPORTATION BY HSR}

There has been a worldwide increase in the number of HSR links and many of them are international ones. The length of HSR network increases day by day as many countries have invested substantially in developing HSR which in 2017 reached 40,832 km [1]. The HSR network is growing internationally as for example, it links France, Belgium, Spain, UK and Germany and in the future, there will be a similar connection between Italy and France. The majority of HSR lines around the world are dedicated to passenger traffic and mainly to one type of trains. However, in a number of countries freight services are operated on HSR. Freight services from Europe to London use HS1. In the UK in 2011-2012 freight moved by trains increased by $10 \%$ compared with the previous year. It was predicted that rail freight will double by 2030 [2]. France and Sweden have the high-speed freight trains delivering post on a regular basis. In France, TGV passenger trains were converted to transport express freight on the railway network that links the North and South. The freight train TGV "La Poste" operates with a maximum speed of up to $270 \mathrm{~km} / \mathrm{h}$ since 1980 -ies but recently it was decided to stop this service because of reduced number of postages and additional costs [3]. With the reducing amount of post, the future of these trains is uncertain. At the moment the freight service in Europe is fragmented, it needs technical standardisation between countries and improved cooperation between infrastructure managers. Germany and Switzerland have the best organized freight rail transportation. Lufthansa partly owns a carrier goods service company that buys capacity from DB running Inter Cargo-Express HS freight trains at speed up to $160 \mathrm{~km} / \mathrm{h}$. In Germany, modified freight trains transporting freight by HSR. The railway network links East-West and North-South of Germany. On the North-South line, the express delivery freight trains are separated half way into two sets which will go to different freight terminals. There is a big difference in loading capacity of freight trains on HSR from 17 tons in China to 50 tons in Germany [4]. The freight trains on HSR in Germany and France operate during the night with a fixed schedule time. The night freight trains are very convenient for express delivery companies. Parcels can be collected on the afternoon, transported during the night, and delivered in the morning. In 2014, new freight rail corridor of 8,100 miles long linked together the People's Republic of China and Spain [5]. It took 19 days to transport freight from Yiwu city in the East of China to Madrid. It is not only faster than transporting by sea, but also it is the most environmentally friendly way of transportation. The railway transportation produces almost three times less carbon dioxide emissions than road transportation [6].

In January 2017, the first freight train from East China, Yiwu arrived at the Eurohub terminal in London. It was a $12000 \mathrm{~km}$ journey through eight countries. Yiwu has one of the largest wholesale hubs for small consumer goods in the world. Transporting by railway is $50 \%$ cheaper than by air and twice as faster than by sea [7]. London was the 15th European city to have direct freight rail services with China. Trains pass western China, Kazakhstan and join the Russian railway network at Yekaterinburg by Trans-Siberian Railway passing through Belarus and Poland. The freight train delivered consumer goods, cloth, high-tech IT products. Now Duisburg and Madrid are receiving trains from China twice per week. It takes on average 16 days to transport goods from China to Europe by railways, but it takes on average 36 days by sea, and the cost is one-fifth of that of transporting cargo by air. The first train from China to Hamburg carried goods valued at 2.33 million dollars [8]. At the present time the railway freight from China is estimated at only $1 \%$ of the total of China's exports, 
but the goal is to increase this to almost $25 \%$ [7]. There is a need to build a number of freight trains from Europe to China. Nowadays they transport to China; aircraft, cars, machinery, chemicals, frozen food products and fashion items.

In recent years, in China there has been an increase in demand for express freight using HSR. In China HSR has been used to deliver parcels since 2012. Express delivery services in China use the passenger Electric Multiple Units (EMU) which carry passengers in addition to parcels located in special luggage sections. Currently approximately $5 \%$ of express cargo is transported by railways in China [4]. Presently China is building a new Rolling Stock (RS) for freight which will be used on HSR, and their design is based on the same principles as existing passenger bullet trains. China is developing two types of freight trains using HSR; super-fast with speed up to $300 \mathrm{~km} / \mathrm{h}$ and fast freight trains with speed up to $160 \mathrm{~km} / \mathrm{h}$. The super-fast freight trains will be competitive with air cargo and fast trains will be competitive with road transportation [9]. These trains will use the HSR which was previously dedicated for passenger trains. China started developing a freight bullet train back to 2014. The freight trains will deliver high value freight such as e-commerce parcels. In China there is a strong tendency to reduce the bulk freight on railways and increase non-bulk freight.

In the USA approximately $40 \%$ of all freight ton-miles and $16 \%$ by tons are accounted for the railway network [10]. In the USA the freight on railways always have priority over passenger trains and if railway lines have some capacity then passenger trains can take it. Because of this, USA has only one HSR, Amtrak's Acela Services, where trains in some parts reach a speed of up to $240 \mathrm{~km} / \mathrm{h}$. This line is from Boston via New York to Washington DC. Amtrak pays approximately only one fifth of the real cost of access to the railway network and one passenger train at $180 \mathrm{~km} / \mathrm{h}$ takes the capacity of six freight trains in any corridor [11]. Amtrak offer freight express services by using their passenger trains to carry freight and post. Modern USA's railway freight services are the best in the world. Transportation time in many cases is shorter than that of road transport. Transportation by rail will takes 66 hours from coast to coast over $4000 \mathrm{~km}$, and by road it takes 4-5 days [12]. The entire railway system in the USA is integrated in one railway network without any border crossings in comparison with railway networks in Europe which is very fragmented with international borders and different topography from country to country. In the USA on some of the Amtrak routes, revenue from express freight and mail traffic provide approximately $40 \%$ of the total revenue. Some of Amtrak long distance trains carry more freight carriages than passengers. Apart from parcel and post Amtrak transported special HS refrigerated carriages that can be coupled in one train with passenger carriages. They found that capacity of refrigerated carriages is approximately three times higher than if the HGV was used [12]. Countries that are transporting freight by HSR are presented in Table 1.

\section{DEMAND FOR EXPRESS DELIVERY SERVICES INCREASES}

The globalisation increased the amount of goods, services and capital that move across borders. A number of small sized goods that is being transported around the world in recent years have raised interest in developing high-speed freight trains [13]. DHL, FedEX, TNT and UPS are the four largest players in the global express industry [14]. These companies offer door-to-door on-time delivery, offer possibility to change the destination and address in transit and possibility to track parcels through every step of its journey. At present, the express freight transportation in Europe is divided between aircraft and trucks. In 2016, air cargo transported 53.9 million tons which represent approximately $35 \%$ of global trade by value. Air transport carries $\$ 15.3$ billion worth of goods every day [15]. DHL express delivery cargo by air in Europe is approximately 5.1 million tons annually. DHL has over 17,000 scheduled departures per week. 
Table 1: Countries transporting freight by HSR.

\begin{tabular}{|l|l|l|l|}
\hline Country & Speed of Freight Trains & Rolling Stock & Type of Freight \\
\hline France & Up to $270 \mathrm{~km} / \mathrm{h}$ & $\begin{array}{l}\text { Converted from } \\
\text { passenger RS }\end{array}$ & Post \\
\hline Germany & Up to $160 \mathrm{~km} / \mathrm{h}$ & Modified freight RS & Post, express delivery \\
\hline Sweden & Up to $160 \mathrm{~km} / \mathrm{h}$ & Modified freight RS & Post \\
\hline USA & Up to $240 \mathrm{~km} / \mathrm{h}$ & $\begin{array}{l}\text { Converted from } \\
\text { passenger RS }\end{array}$ & Post, express delivery \\
\hline China & $\begin{array}{l}\text { Up to } 160 \mathrm{~km} / \mathrm{h} \\
\text { Up to } 300 \mathrm{~km} / \mathrm{h}\end{array}$ & $\begin{array}{l}\text { Special designed RS } \\
\text { Special designed RS }\end{array}$ & $\begin{array}{l}\text { Express delivery } \\
\text { Post, express delivery }\end{array}$ \\
\hline
\end{tabular}

Data taken from various resources

In the UK DHL has 30 aircraft, 24 of them are Boeing 757 and 6 Boeing 767 [16]. The maximum payload of Boing B737 is between 19 and 100 tons depending on the type of aircraft [17]. To transport 5 million tons of express delivery freight only in Intra-Europe, a hundred thousand flights per year are needed. The express delivery industry very much depends on overnight transportation and in this case HSR can have a good opportunity to expand business by offering express freight services. Express services industry uses a variety of different transportation modes and HSR can be one of them. In the USA the express delivery service in 2003 accounted for over $60 \%$ of the domestic air cargo market. IntraEurope express market response is $34 \%$ of the global express market [14]. Shifting freight from roads and air to railways can reduce congestion on roads and airports, reduce the amount of fuel used by the transport industry and reduce greenhouse gas emissions. A ton of freight carried by train produce $90 \%$ less carbon dioxide emission compares to road transportation [18]. Furthermore, taking lorries from roads will be a substantial reduction in the costs of maintenance of roads. Fuel oil is the finite mineral resource and prices of oil inevitably will increase and it was estimated that costs of freight transported by roads will increase by $36 \%$ by 2040 [19]. In 2015, the biggest four online shopping markets in the world were: UK, US, Germany and China. It would double in size by 2018 [20]. The goods transported by air accounts for only $3 \%$ of the total freight weight but hold $40 \%$ of the total value [14].

Fig. 1 shows the growing online retail market in billions of pounds. The online sales approximately increase by $14 \%$ year on year. UK, Germany and France dominated the European market and they are responsible for $75.1 \%$ of the total online sales in Europe. 52\% of the population in Europe and $66 \%$ of the population in USA shop online. In Europe online sales were expected to grow by $32 \%$ in period 2015-2017 [21]. British retailers are the most popular for German consumers and second most popular for China and USA consumers [20]. In Europe, express services deliver approximately 260 million packages each year and move approximately six million packages everyday worldwide. Growth rate is between $25 \%$ and $35 \%$ annually and international trade is expected to increase by approximately $70 \%$ between 2009 and 2019 [22]. 


\section{Online retail market in $£$ billion}

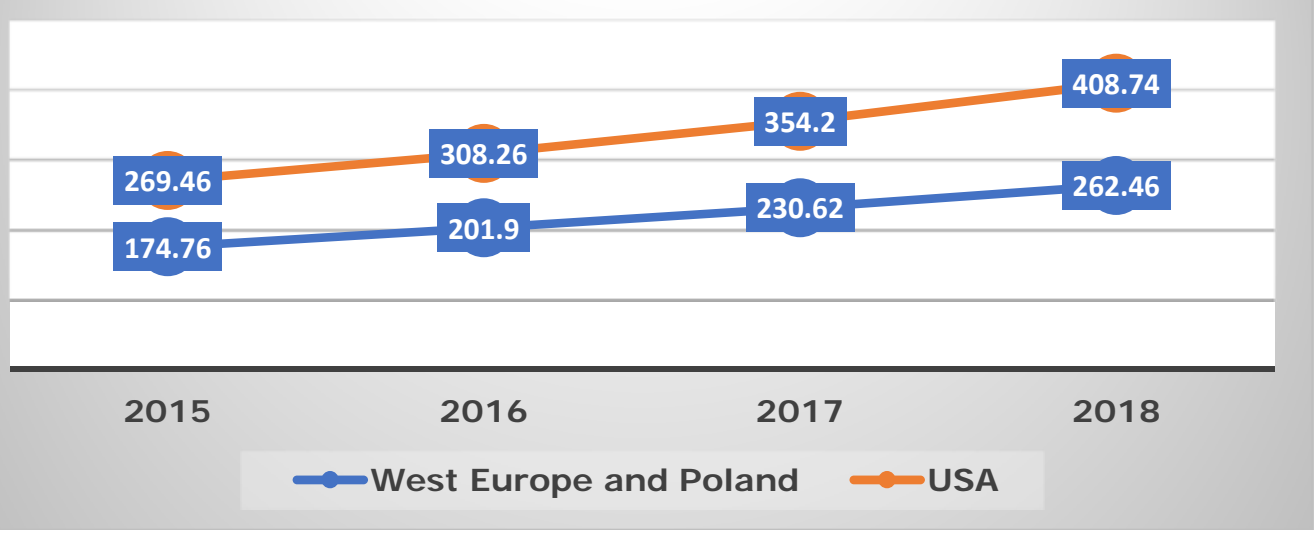

Figure 1: Online retail market 2015-2018. (Source: Adapted from [21].)

Fig. 2 shows the growth in goods trade between EU and China which is annually increasing on average by $4.2 \%$. The online shopping market in China in 2014 reached 2.8 trillion CNY (China Yuan) and has an annual growth rate of 48.7\% [4]. Rapidly growing online market in Asia-Pacific region overtake USA, reaching \$500 billion [24]. Expanding the online retail market increases the share of express delivery services whilst the air cargo market will grow by $7 \%$ year on year [25]. One third of high value goods transported between China and Europe is transported by air [26]. In the future the importance of express delivery services will only increase as world economy becomes more integrated and express delivery services minimize the inventory costs.

\section{EU trade in goods with China}

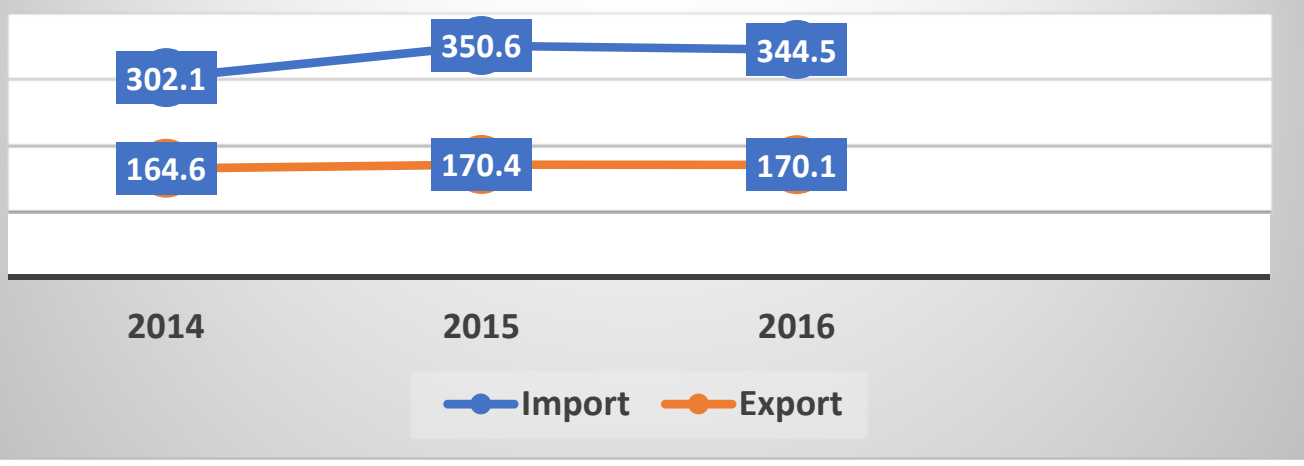

Figure 2: EU trade in goods between 2014 and 2017 in billion EUR. (Source: Data taken from [23].) 


\section{VISION FOR THE FUTURE FREIGHT TRANSPORTATION BY HSR}

There is an obvious increase in the demand for express delivery worldwide, but up to now the main transportation modes are road and air transport. In relation to air transport there are many restrictions on night flights, but HSR can offer overnight delivery. Freight using HSR will be cheaper to deliver than by air and faster than by road. To make HSR competitive with air in transporting freight, express delivery needs to standardize the infrastructure, harmonize the operational management and safety management and improve the coordination between states across all of Europe.

The medium-distance high-speed freight trains can replace some of the short cargo flights and lorries. The long-distance high-speed freight trains can replace some of the cargo flights and shipping by the sea. The airports get more congested and delays are increasing. For example, punctuality of London Heathrow is approximately 76\%. [27]. The express delivery services are very sensitive to the delays. HSR is more reliable and by shifting express delivery freight from air to HSR there will be a reduction in the congestion at airports. The vacated capacity can be used for additional long-distance flights. Railways use less land, produce less pollution and noise. Some of the benefits of running express freight train on HSR are:

- HSR is more reliable, punctuality ratio varies between $90 \%$ and $99 \%$ [28].

- Long distance transit is cheaper by rail, than by road, shipping or air.

- Freight transportation by rail emits less pollution than road, air or shipping by sea.

- Freight transportation by HSR is not dependent on fossil fuel, which is a finite mineral resource.

- Shifting freight to HSR will reduce the number of accidents and road and airport congestion.

It was estimated that in the UK alone the road congestion cost for UK businesses reached $£ 24$ billion per year [29]. Removing one HGV from the road is equivalent to moving four standard cars [30].

Development of high-speed freight transportation will bring huge economic, operational and social opportunities for society. It can reduce the number of short cargo flights in Europe, reduce the number of lorries on roads, reduce the carbon dioxide emissions, and attract new enterprises to transport freight by HSR and to develop new freight terminals. Development of high-speed freight transportation will reduce the dependency on fossil fuel. More than $60 \%$ of the population supports an increase in freight transportation by rail [31].

There are two ways to increase the HSR share in freight transportation. Increasing the number of hubs which connect air and HSR may allow HSR to deliver freight to airports or as a main transportation mode. There are two ways to operate freight express service; services can be integrated with high-speed passenger trains or express freight transported by special high-speed freight trains. Developing the Rail Freight Corridors and implementing the European Rail Traffic Management System (ERTMS) mean that railways will attract more freight from other modes of transportation, and will raise the railway efficiency, punctuality, reliability and service quality. Europe has an increasing number of HSR links and many of them are international which increases the integration between different railway networks.

Linking major air cargo hubs in Europe by high speed freight transportation can be an alternative to short haul air cargo routes. Cargo flights between London, Paris, Amsterdam and Frankfurt can be replaced by high-speed rail freight trains and this will reduce the carbon dioxide emissions, reduce the noise level, reduce the congestion at airports and improve the long-distance air cargo connectivity. Very often there are constraints on land due to the expansion of airports and highways. Railways use less land than roads or airports and offer 
more capacity. However, mixed traffic on HSR will have a considerably bigger effect on the maintenance of the infrastructure and will reduce the time that is available for maintenance. There is a need to better coordinate cooperation between infrastructure managers when major maintenance is needed.

\section{PLANNED ALTERNATIVES FOR THE FUTURE DELIVERY OF FREIGHT TRANSPORTATION BY HSR}

One of the biggest infrastructure projects of the twenty-first century is what is called "Silk Road", which is intended to link Europe with Asia. One of the links will be by a railway. The railway will pass through many countries and one of them is Russia. With the rise of ecommerce between Europe and China, Russian Railways (RZD) is working to develop a concept for a high-speed freight train that can achieve 2-3 days transit time across Russia. Freight trains will carry high value low weight express freight between Russia and China. It will start with Moscow-Kazan high-speed line but with a future expansion to Europe and China. China and Germany are developing a concept for 12-car high-speed railway train that will carry passengers and freight and travel at a speed of up to $400 \mathrm{~km} / \mathrm{h}$ [26]. RZD are planning to start to construct HSR that will connect Moscow-Kazan $(770 \mathrm{~km})$ with future connection to Ekaterinburg $(1595 \mathrm{~km})$ in 2019. Night trains from Moscow to Ekaterinburg will cover $1595 \mathrm{~km}$ in 14 hours. Kazan is one of the largest cities in Russia with huge industry. The building of a new HSR will bring a significant reduction in travel time. At the present, it takes 14 hours 7 minute to get from Moscow to Kazan by train whilst using the new HSR a journey will take 3 hours and 30 minutes. It would be mixed-HSR with a $400 \mathrm{~km} / \mathrm{h}$ design speed for the super high-speed trains whilst the intercity trains will travel at $200 \mathrm{~km} / \mathrm{h}$ and night long distance trains and freight trains will travel at a speed of up to $160 \mathrm{~km} / \mathrm{h}$. HSR line will have two ballast less tracks with a gauge of $1520 \mathrm{~mm}$. One of the stations will be at Nizhniy Novgorod airport [32]. Nizhniy Novgorod is a major transportation and distribution hub in Russia. It lies on the route between China and Europe and the amount of Chinese goods that is being distributed through this hub increases every year by approximately $8 \%$ [8]. China will invest in this project $\$ 5.9 \mathrm{bn}$ as it will be part of the "Silk Road" that will connect Europe with Asia [33]. The total cost of HSR between Moscow and Kazan will be $\$ 30 \mathrm{bn}$ and it will be subsidised through public-private partnership [34].

"Euro Carex" is a project in Europe that is expected to use the existing HSR network for freight transportation to carry air containers [35]. The first phase is to develop express freight services on HSR between five locations: Amsterdam Schiphol, Liege Bierset, London, Lyon Saint-Exupery and Paris-Roissy CDG. Several express parcel delivery services supported this project, the largest of them are: UPS and FedEx from USA, and TNT Express from the Netherlands. The aim of the project is to link freight airports with HSR and transport freight between these airports instead of short flights, and to reduce the number of truck and van journeys to and from airports. One train will be able to carry between 100-140 tons of freight [36].

These new projects have become possible thanks to the new technological innovations in signaling systems and traffic management systems that opened new opportunities for mixed traffic using HSR. ETCS Level 2 trains can be run at intervals of 3 minutes. In order not to affect the line capacity, it is important that the speed of passenger and express freight trains must be as close as possible. The Swiss Traffic Management software 'Rail Control System (RCS)' can sufficiently increase the capacity of railway lines. Alternative Double Single Track (ADST), is another way to increase the capacity of railway infrastructure. It implies building parallel double stretches of track in low-cost areas where passenger trains can overtake freight on the parallel track. For example, Nuremberg-Berlin new mix HSR line has 
overtaking stations every $20 \mathrm{~km}$. Freight trains can drive there and let the faster passenger train overtakes. Freight trains can directly roll into the container terminal in Leipzig or the air freight transfer station. Newly designed cargo trains on HSR are based on passenger rolling stock and will be organized as passenger trains. This will reduce the line capacity issues, as freight multiple units can travel at the same speed as passenger trains. Axle loading of freight multiple unit must be close to axle loading of passenger multiple unit as high-speed railway tracks commonly have a gradient step as much as $2.5 \%$ to $4 \%$.

\section{SOME OF TECHNICAL AND OPERATIONAL CONSTRAINTS FOR HIGH-SPEED FREIGHT TRAINS}

Currently the freight services in Europe are fragmented and need technical standardisation across various countries and improvement in the cooperation among different infrastructure managers. There is a need to investigate the capability of existing HSR to transport freight and technical and operational constraints concerning mixed traffic. Another serious constraint is the increasing cost of maintenance of mixed lines. Maintenance of mixed lines is expensive and needs much longer time to be done. However, there is a good example at Trenitalia, where by introducing the Dynamic Maintenance Management System (DMMS) on Trenitalia trains, the maintenance cost will be reduced by $7-8 \%$ [37]. Increasing the preventative maintenance instead of the reactive one and increasing the number of real-time sensors that monitor the conditions of existing railway infrastructure and rolling stock may mean that there will be a sufficient reduction in maintenance and decreases in the time window that is allocated for maintenance in addition to the fact that it would be possible to allocate more time at night for freight services.

Development of suitably designed and located terminals is another constraint for freight transportation on HSR. Terminals are a place where freight enters and leaves the railway system and they are hugely important for efficient and sustainable performance of railways. There is a need to develop road-rail-air terminals to close the gap between road and rail and rail and air. They can be located near airports or near railway stations. However, developing new HSR terminals may require substantial investments in new HSR infrastructure. All HSR stations are constructed for passenger purpose only. With the increasing demand for freight express delivery services and the introduction of freight trains using HSR, there is a need to construct new freight yards and terminals which can be located near HSR stations or near local express distribution centres and these can be connected with the HSR through a branch line. Freight transport on HSR could face a problem in terms of creating a timetable as freight trains do not follow a regular timetable. They fluctuate at short notice to meet demand and this affect the line capacity. There are also some infrastructure constraints as high-speed freight train should be able to operate on dedicated HSR with step gradient.

\section{CONCLUSIONS}

The European HSR systems in different countries have different configuration and technical requirements. Predicted ridership for a newly developed HSR in many cases is overestimated but in reality, demand is much lower. Introducing the HSR express freight traffic can significantly improve the economic sustainability of HSR. There is an obvious change in types of freight that is transported by railways and there is a need to adapt to this. There is a new growing market. Use of internet is expanding and increasing the mobile shopping and e-commerce. The express delivery industry is growing rapidly, and it is one of the fastest growing sectors of the economy which means that there are new opportunities for express freight using HSR. With the increasing integration in global economy, share of guaranteed express delivery services will only increase. In recent years requirements of users changed 
substantially, people expect more product variety, next day delivery, and door-to-door delivery. To satisfy this demand there is a need for a higher level of variety and reliability in the supply chain.

HSR can move freight in the most sustainable way and can sufficiently improve the trade links within Europe and between Europe and Asia. HSR has the ability to move goods quickly, safely and cost-effectively. Using the HSR for express freight transportation will significantly increase capacity of conventional railways for bulk freight, reduce the delivery time, and will increase the utilization of HSR lines. In some countries, such as Spain, there is quite low line utilization. The HSR is not affected by traffic congestion as air transportation as it has very high degree of punctuality, and with the increasing number of extreme weather events it is a strong competitor in terms of time and cost. Freight trains that are operated and organized as passenger trains will not affect the punctuality of HSR passenger trains and will not affect capacity of the line.

There is a new opportunity for express freight trains using HSR. Railways can transport freight from China quicker, cheaper and greener despite the need of gauge changes and crosscountry borders. The HSR can offer fast, reliable and convenient way to transport high value low weight goods. The increased concern about the negative influence on the environment, increased fuel prices and congestion at roads and airports highlight the importance of HSR as a good alternative for express freight transportation.

\section{REFERENCES}

[1] High Speed lines in the world, 2017. http://uic.org/IMG/pdf/20170901_high_speed_ lines_in_the_world.pdf. Accessed on: 6 Nov. 2017.

[2] Is High Speed Rail the Future of European Freight? Marpakm 2017. http://marpak.co. uk/is-high-speed-rail-the-future-of-europeanfreight/. Accessed on: 26 Oct. 2017.

[3] Taylor, I., La Poste to Streamline Courier Products and Invest in Rail Transport Post\&Parcel. Post\&Parcel, 2014. http://postandparcel.info/61633/news/companies/ la-poste-to-streamline-courier-products-and-invest-in-rail-transport/. Accessed on: 18 Jan. 2018.

[4] Liang, X., Tan, K., Whiteing, A., Nash, C. \& Johnson, D., Parcels and mail by high speed rail - A comparative analysis of Germany, France and China. Journal of Rail Transport Planning \& Management, 6(2), pp. 77-88, 2016.

[5] McAvoy, K., China's Freight System Future: Is a High-Speed Rail Possible? Spend Matters, 2015. https://spendmatters.com/2015/01/08/chinas-freight-system-future-isa-high-speed-rail-possible/. Accessed on: 26 Oct. 2017.

[6] Burgen, S., The Silk Railway: freight train from China pulls up in Madrid. The Guardian, 2014. https://www.theguardian.com/business/2014/dec/10/silk-railwayfreight-train-from-china-pulls-into-madrid. Accessed on: 5 Nov. 2017.

[7] Smith, K., China-Europe Rail Freight Continues to Soar, 2017. http://www.railjournal.com/index.php/freight/china-europe-rail-freight-continues-tosoar.html. Accessed on: 18 Jan. 2018.

[8] Wa, Z., Rail route to Europe improves freight transport. China Daily Europe, 2017. http://europe.chinadaily.com.cn/world/2013-09/13/content_16966629.htm. Accessed on: 5 Nov. 2017.

[9] China considering high-speed freight trains, 2017. https://www.rwfreight.co.uk/news/ 2014/08/27/china-considering-high-speed-freight-trains-123/. Accessed on: 10 Nov. 2017.

[10] Freight Rail Overview, Federal Railroad Administration, 2017. https://www.fra. dot.gov/page/P0362. Accessed on: 5 Nov. 2017. 
[11] The Economist. High-speed Railroading, 2010. http://www.economist.com/ node/16636101. Accessed on: 18 Jan. 2018.

[12] Troche, G., High-speed rail freight, sub-report in Efficient train systems for freight transport, 2005. https://www.kth.se/polopoly_fs/1.87134!/Menu/general/columncontent/attachment/0512 inlaga.pdf. Accessed on: 3 Nov. 2017.

[13] Rita.dot.gov. Bureau of Transportation Statistics, 2004. https://www.rita.dot.gov/ bts/sites/rita.dot.gov.bts/files/publications/freight_shipments_in_america/html/entire. html. Accessed on: 18 Jan. 2018.

[14] The Impact of the Express Delivery Industry on the global economy, 2005. https://global-express.org/doc/Global_Express_Impact_Study.pdf. Accessed on: 5 Nov. 2017.

[15] IATA Annual Review, 2017. https://www.iata.org/publications/Documents/iataannual-review-2017.pdf. Accessed on: 8 Nov. 2017.

[16] DHL Air Fleet Details and History, 2017. https://www.planespotters.net/airline/DHLAir. Accessed on: 8 Nov. 2017.

[17] Boeing 737-300F, Fast Freight Aircraft .Air Partner, 2017. http://www.airpartner.com/ en/aircraft-guide/boeing-b737-300f/. Accessed on: 8 Nov. 2017.

[18] Rail Freight: Facts and Myths, 2005. http://www.freightonrail.org.uk/PDF/ FactsandMyths.pdf. Accessed on: 4 Nov. 2017.

[19] High speed freight - food for thought, 2017. http://www.rail.co.uk/railnews/2013/high-speed-freight-food-for-thought/. Accessed on: 26 Oct. 2017.

[20] Ruddick, G., Online shopping to grow by $£ 320 \mathrm{bn}$ in three years, 2015. http://www.telegraph.co.uk/finance/newsbysector/retailandconsumer/11657830/Onli ne-shopping-to-grow-by-320bn-in-three-years.html. Accessed on: 8 Nov. 2017.

[21] Online Retailing: Britain, Europe, US and Canada 2017 - Centre for Retail Research, Nottingham UK, 2017. http://www.retailresearch.org/onlineretailing.php. Accessed on: 8 Nov. 2017.

[22] The European Express Association - Facts \& Figures on the express industry, 2017. http://euroexpress.org/facts-figures. Accessed on: 8 Nov. 2017.

[23] European Commission, Directorate-General for Trade, China, 2017. http://trade.ec. europa.eu/doclib/docs/2012/march/tradoc_149251.pdf. Accessed on: 8 Nov. 2017.

[24] The future of retailing - Smart Insights Digital Marketing Advice, 2017. https://www.smartinsights.com/ecommerce/ecommerce-strategy/the-future-ofretailing/. Accessed on: 8 Nov. 2017.

[25] The impact of the Express Delivery Industry on the Global Economy, 2009. http://www.euroexpress.org/uploads/ELibrary/REPORTS. Accessed on: 8 Nov. 2017.

[26] K. RZD develop plans for high-speed rail freight. International Railway Journal, 2017. http://www.railjournal.com/index.php/high-speed/rzd-develops-plans-for-high-speedrail-freight.html?channel=527. Accessed on: 9 Nov. 2017.

[27] FLIGHTONTIME.info - London Heathrow Airport Flight Delays \& Punctuality, 2017. http://www.flightontime.info/scheduled/airports/lhr16.html. Accessed on: 4 Nov. 2017.

[28] Watson, I., Ali, A. \& Bayyati, A., Investigation of the operational reliability of highspeed railway and possible measures of improvement. Railway Engineering, Edinburgh, 2017.

[29] Rail Freight Benefits, 2017. http://freightarranger.co.uk/rail-freight-benefits. Accessed on: 4 Nov. 2017.

[30] Reducing congestion, 2017. http://www.railtechnologymagazine.com/Comment/ reducing-congestion. Accessed on: 4 November 2017. 
[31] Two-thirds of public support rail freight investment boost, poll finds, 2017. http://www.railtechnologymagazine.com/Rail-freight/two-thirds-of-public-supportrail-freight-investment-boost-poll-finds. Accessed on: 4 Nov. 2017.

[32] Oprf.ru. Проект строительства участка «Москва - Казань» высокоскоростной железнодорожной магистрали «Москва - Казань Екатеринбург», 2014. https://oprf.ru/files/MemoMoscow-KazanRU.pdf. Accessed on: 18 Jan. 2018.

[33] Китай вложит \$5,9 млрд в магистраль Москва-Казань. ВВС Русская служба, 2015. http://www.bbc.com/russian/business/2015/05/150508_china_russia_railway. Accessed on: 28 Oct. 2017.

[34] Railway Technology. Moscow-Kazan High-Speed Rail Line - Railway Technology, 2018. http://www.railway-technology. projects/moscow-kazan-high-speed-rail-line. Accessed on: 18 Jan. 2018.

[35] Roissycarex.com. The European Very High-Speed Rail Freight Network, 2013. http://www.roissycarex.com/pdf/pressreview/112711760542_carex-pressreview.pdf. Accessed on: 18 Jan. 2018.

[36] Euro Carex a driver for economic growth, 2017. http://eurocarex.com/pdf/pressreview/ 092003432256_carex-pressreview.pdf. Accessed on: 9 November 2017.

[37] Finnegan, M., Trenitalia to Cut Train Maintenance Costs with SAP IoT and Big Data Project, 2016. https://www.computerworlduk.com/iot/trenitalia-cut-trainmaintenance-costs-with-iot-big-data-project-3647262/. Accessed on: 18 Jan. 2018. 